\title{
Post-Harvest Activities and Marketing Behaviour Followed by the Farmers in Redgram Based Farming System
}

\author{
Ashok Kumar Melkeri ${ }^{1 *}$, S. K. Meti ${ }^{1}$, D. M. Chandargi ${ }^{1}$ and S. S. Patil ${ }^{2}$ \\ ${ }^{1}$ Department of Agricultural Extension Education, \\ University of Agricultural Sciences, Raichur, Karnataka, India \\ ${ }^{2}$ Department of Agricultural Economics, \\ University of Agricultural Sciences, Raichur, Karnataka, India \\ *Corresponding author
}

\section{Keywords}

Post-harvest activities,

Marketing

behaviour,

Kalaburagi,

Redgram

\section{Article Info}

Accepted:

15 March 2020

Available Online:

10 April 2020

\begin{abstract}
A B S T R A C T
The present study was conducted in Kalaburagi district of North Eastern Karnataka, during the year 2018-19. Kalaburagi district was purposively selected because the district is the pulse bowl of the state with highest area. The study was conducted in eight villages selected from four talukas of Kalaburagi district which included 30 farmers from each selected village thus making a sample of 240 farmers using random sampling method. Expost-facto research design was employed for conducting study. Data was collected by using a detailed interview schedule employing personal interview method and analysed using mean, standard deviation, frequency and percentage. The major findings of the postharvest activities revealed that, cent per cent of the farmers used jute bags to store the produce; farmers do not use processing the redgram seeds. Over half 56.25 per cent of the farmers used redgram stalk as fuel as consumption purpose. About 43.75 per cent of the farmers used redgram stalk for compost preparation and marketing behaviour revealed that, majority $(88.75 \%)$ of the farmers used mode of transport as tractor. About $(78.33 \%)$ of the farmers received market price information over phone to the market/personal visit. While $(67.92 \%)$ of the farmers sold their produce immediately after the harvest whatever the prices may be, whereas, $(59.17 \%)$ of the farmers sold their produce to government agencies APMC.
\end{abstract}

\section{Introduction}

Redgram (Cajanus cajan (L) mill. sp.) is commonly known as arhar, pigeonpea, tur, togari, gango pea and no eye pea. It is an important and old crop of the country. It is the second most important pulse crop only after chickpea. Redgram is an important pulse crop grown in the tropics and subtropics. It finds important place in farming systems adopted by small holding peasants in large number of developing countries. Redgram is considered to be origin of peninsular India. It is a short annual crop in India and as a perennial in many other countries, where pods are harvested at regular interval. The crop has 
deep root system and hence highly drought tolerant. It is a protein rich staple food contains about 22.30 per cent protein, which is almost three times that of cereals.

Redgram supplies a major share of protein, requirement of vegetarian population of the country. Redgram is mainly consumed in the form of split pulse as Dal, which is an essential supplement of cereal based diet (Nene and Sheila, 1990, Tuwafe et al., 1993).

India is the largest producer, consumer and importer of redgram in the world. India occupies 79.00 per cent of world redgram area and accounts for 67.00 per cent of world production of redgram. Redgram occupies an area of 4.44 million hectares and production of about 4.28 million tonnes, having a productivity of $967 \mathrm{~kg} / \mathrm{ha}$ (INDIASTAT, 2017). It is mainly grown in Maharashtra, Karnataka, Madhya Pradesh, Telangana, Uttar Pradesh and Andhra Pradesh. Maharashtra (1.24 million hectares) is the leading producer of redgram followed by Madhya Pradesh (0.64 million hectares).

In Karnataka, redgram is largely grown in northern parts, especially in Kalaburagi district and is called as pulse bowl of Karnataka. 'Kalaburagi Tur Dal' received Geographical Indication (GI) Tag (No. 593) from government of India during the year 2019. The state occupies an area of about 8.85 lakh hectares with the production of 7.62 lakh tonnes, having an average productivity of 861 $\mathrm{kg} / \mathrm{ha}$ (INDIASTAT, 2017). Kalaburagi has an area of about 3.28 lakh hectares with production of 3.77 lakh tonnes and a productivity of $1209 \mathrm{~kg} / \mathrm{ha}$ (Directorate of Economics and Statistics, Bengaluru, 2017).

Hence, it is evident that redgram crop command greater importance for attaining a better position in the world market, which would inturn contribute to our national income. At the same time, there is a need to concentrate on certain post-harvest activities and marketing behaviour followed in redgram based farming system.

Post-harvest and marketing behaviour is a chain of interconnected activities from the time of harvest to the delivery of the food to the consumers. Agricultural commodities produced on the farm have to undergo several procedures like harvesting, drying, threshing, winnowing, processing, bagging, storage, transportation, and exchange before reaching the final consumer.

The primary role of an effective post-harvest system is to ensure that the harvested food reaches the consumer, while fulfilling customer satisfaction in terms of quality, volume and safety. A post-harvest loss of fruits and vegetable is 22 to 40 per cent, pulses, oilseeds and cereals is 10 to 30 per cent. These losses mainly arise because of improper harvesting methods, problems of threshing, storing, transportation and processing leads to large-scale losses in food grains.

Thus, the post-harvest losses obviously have an impact on the economy. Hence, there is thinking that, there is a considerable loss of redgram in post-production operations. There are no specific recommendations made as those of improved varieties of crops and there production technology. Farmers based on their experience do adopt post-harvest technology.

Some innovative farmers might have adopted the scientific post-harvest technologies. But, there is no information on these aspects. Keeping these facts and figures in mind, the present study was conducted with an objective to know the post-harvest activities and marketing behaviour followed by the farmers in redgram based farming system. 


\section{Materials and Methods}

The research study was conducted in Kalaburagi district of Karnataka state during the year 2018-19. Kalaburagi district was purposively selected because the district is the pulse bowl of the state with highest area. Out of seven talukas from the Kalaburagi district four talukas were selected purposively based on highest area under redgram cultivation. The talukas selected for the study were Aland, Chittapur, Jewargi and Kalaburagi. A list of villages where redgram is grown as principal crop is prepared in consultation with the officials of Department of Agriculture.

Two villages from each talukas were selected based on maximum area under redgram cultivation. The villages selected for the study were Madan Hipperga and Narona from Aland taluka, Kalgi and Dandothi from Chittapur taluka, Yedrami and Nelogi from Jewargi taluka and Kamalapur and Srinivas Saradagi from Kalaburagi taluka. Thus a total of eight villages were selected from four talukas. Considering all the farmers in the selected villages, the criteria for selection of farmer as a respondent is that, he should successfully cultivate redgram crop.

Along with redgram one or the other intercrops and enterprises like dairy (minimum two milch animals), sheep/goat farming (minimum of four sheep's/goat/unit), poultry rearing etc. From the each selected village, a separate list of redgram based farmers was prepared in consultation with officials of Department of Agriculture. From the list prepared, 30 farmers were selected randomly by using simple random sampling technique.

Thus, the study sample comprised of 240 respondents. Ex-post-facto research design was employed for conducting study. Data was collected by using a detailed interview schedule employing personal interview method. The responses were scored, quantified, categorized and tabulated using percentage, mean and standard deviation.

\section{Results and Discussion}

\section{Post-harvest activities carried out by the} farmers in redgram based farming system

The data from the Table 1 indicated that, cent per cent of the farmers used jute bags to store the produce; farmers do not use processing of redgram seeds. Over half 56.25 per cent of the farmers used redgram stalk as fuel as consumption purpose. About 43.75 per cent of the farmers used redgram stalk for compost preparation. While 20.00 per cent of the farmers used method of storage for their produce was on the ground. About 10.83 per cent of the farmers used method of drying under sunlight. Only 8.75 per cent of the farmers used manually winnowing at the time of cleaning.

The probable reason for jute bags might be that jute bags are cheaper and more durable than other bags like Polythene bags, cloth bags, etc. Without processing the produce might be that most of the farmers are unaware of processing process in redgram. Most of the farmers used redgram stalk as fuel consumption purpose because most of framers are dependent on firewood cooking in rural areas than any other source.

One third of the farmers used redgram stalk for preparing the compost in their field. Method of storage of their produce was on the ground. The reason for drying helps the farmers to get better price. Only less per cent of farmers have cleaned their produce by manually winnowing at the time of cleaning because most of the farmers have harvested their redgram crop by mechanical thresher and mechanical combined harvester. 
Marketing behaviour followed by the farmers in redgram based farming system

The data presented in the Table 2 indicated that majority $(67.92 \%)$ of the farmers sold their produce immediately after the harvest whatever the prices may be followed by 20.83 per cent of farmers sold their produce immediately after the harvest, if prices are favourable and 11.25 per cent of farmers sold their produce if the prices are less, then produce will be stored for some time.

The probable reason could be the need of money for family purpose and also they brought the fertilizers and pesticides from input shop without paying the money. So to pay the amount to input shop the farmers had sold their produce immediately after the harvest whatever the price may be.
With regard to mode of transportation majority $(88.75 \%)$ of the farmers used mode of transport as tractor followed by 11.25 per cent tata-ace/tata 407 for transportation. The probable reason could be that almost all the farmers harvested redgram crop at the same time and in the village level one to two farmers heir the tractor on rent basis and sell their produce to market the transportation charges will be low to each of the farmers than the tata-ace.

The tata-ace/tata 407 heired fetches more prices and quantity of transportation is less in tata-ace. While $(59.17 \%)$ of the farmers sold their produce to government agencies APMC, followed by 15.83 per cent of farmers to wholesalers through commission agents, to village level traders 13.75 per cent, then processing mills 11.25 per cent.

Table.1 Post-harvest activities carried out by the farmers in redgram based farming system $(n=240)$

\begin{tabular}{|c|c|c|c|}
\hline Sl. No. & Post-harvest activities & Frequency & Percentage \\
\hline \multirow[t]{3}{*}{1.} & \multicolumn{3}{|l|}{ Method of drying } \\
\hline & Under shade & 0 & 0.00 \\
\hline & Under sunlight & 26 & 10.83 \\
\hline \multirow[t]{3}{*}{2.} & \multicolumn{3}{|l|}{ Grading the produce } \\
\hline & Manually winnowing at the time of cleaning & 21 & 8.75 \\
\hline & Mechanic (Scientific sieves) & 0 & 0.00 \\
\hline \multirow[t]{3}{*}{3.} & \multicolumn{3}{|l|}{ Bags used to store the produce } \\
\hline & Gunny (Jute) bags & 240 & 100.00 \\
\hline & Polythene bags & 0 & 0.00 \\
\hline \multirow[t]{3}{*}{4.} & \multicolumn{3}{|l|}{ Method of storage of the produce } \\
\hline & On the ground & 48 & 20.00 \\
\hline & Under the ground & 0 & 0.00 \\
\hline \multirow[t]{3}{*}{5.} & \multicolumn{3}{|l|}{ Processing of the produce } \\
\hline & Without processing & 240 & 100.00 \\
\hline & After processing (Local dhal mills) & 0 & 0.00 \\
\hline \multirow[t]{3}{*}{6.} & \multicolumn{3}{|l|}{ Utilization pattern of redgram stalks } \\
\hline & Redgram stalk used as fuel & 135 & 56.25 \\
\hline & Compost preparation & 105 & 43.75 \\
\hline
\end{tabular}


Table. 2 Marketing behaviour followed by the farmers in redgram based farming system $(n=240)$

\begin{tabular}{|r|l|c|c|}
\hline Sl. No. & \multicolumn{1}{|c|}{ Marketing behaviour } & F & $\%$ \\
\hline 1. & Time of sale of the produce & 50 & 20.83 \\
\hline i. & Immediately after the harvest, if prices are favourable & 163 & 67.92 \\
\hline ii. & Immediately after the harvest whatever the prices may be & 27 & 11.25 \\
\hline iii. & $\begin{array}{l}\text { If the prices are less, then produce will be stored for some } \\
\text { time }\end{array}$ & & \\
\hline 2. & Mode of transportation & 213 & 88.75 \\
\hline i. & Tractor & 27 & 11.25 \\
\hline ii. & Tata ace/ tata 407 & 33 & 13.75 \\
\hline 3. & Place of sale of the produce & 142 & 59.17 \\
\hline i. & To village level traders & 38 & 15.83 \\
\hline ii. & To Government Agencies (APMC) / Market yard & 27 & 11.25 \\
\hline iii. & To wholesalers through commission agents & & \\
\hline iv. & To processing mill & 13 & 5.41 \\
\hline 4. & Information source for market price* & 27 & 11.25 \\
\hline i. & Newspaper & 188 & 78.33 \\
\hline ii. & Mobile SMS & 134 & 55.83 \\
\hline iii. & Personal visit/over phone to the market & & \\
\hline iv. & Other who visited market & & \\
\hline & & & \\
\hline
\end{tabular}

APMCs are procuring redgram with a good constant price in the market there is no fluctuation price in the APMCs the rate is fixed by the government. Commission agents are having good exposure to the market and having contact with large buyers.

Hence, farmers were selling their produce through commission agents also for a good price and can create demand in the market. About less per cent of farmers were also selling their produce to the local village level traders and only few per cent of farmers were selling their produce directly to processing dall mills. Information source for market price nearly eighty per cent $(78.33 \%)$ of them received market price information over phone to the market/personal visit followed by 55.83 per cent of them received market price information other who visited market, through mobile SMS 11.25 per cent and newspaper 5.41 per cent, respectively.

It is very easy and cheapest source of getting the market information through phone or personal visit. It can be concluded that majority of the farmers had not adopted postharvest activities and marketing behaviour 
such as drying, grading, without processing and processing mill. Though the farmers are in hurry to sell their produce due to economic compulsion, the policy makers and other agencies have to come forward to finance the growers in advance.

There is a need to create awareness among the redgram based farmers regarding the importance of post-harvest activities and marketing behaviour for getting higher income through intensive extension activities.

\section{References}

Govinda Gowda and Narayana Gowda, K., 2004, An analysis of adoption of postharvest management practices and engineering equipments among grape growers. Mysore J. Agric. Sci., 38 (2): 273-277.

Mohanakumar, V., 2016, Adoption of postharvest management practices in pigeonpea crop for sustainable income. Int. J. Sci. and Nature, 7 (3): 492-495.

Nene, Y. L. and Sheila, V. K., 1990, Pigeonpea geography and importance, in Nene, Y. L., Susan, D., Hall and
Sheila, V. K., the pigeonpea. C. $A . B$. international ICRISAT, India. 1-13.

Raghavendra, M. R., 2004, Knowledge and adoption of post-harvest technologies by redgram cultivators in Gulbarga district of Karnataka. M. Sc. Thesis, Univ. Agric. Sci. Dharwad (India).

Ravikumar, D. M., 2010, A study on knowledge and adoption of post-harvest management practices among the mango growers of Northern Karnataka. M. Sc. thesis, Univ. Agric. Sci., Dharwad (India).

Sidram, 2008, Analysis of organic farming practices in pigeonpea in Gulbarga district of Karnataka state. M. Sc. Thesis, Univ. Agric. Sci., Dharwad (India).

Sunilkumar, G. M., 2004, A study on farmers knowledge and adoption of production and post-harvest technology in tomato crop of Belagum district in Karnataka. M. Sc. Thesis, Univ. Agric Sci. Dharwad (India).

Tuwafe, S., Silim, S. N. and Singh, L., 1993, ICRISAT/AFDB Pigeonpea importance project in Easter and Southern Africa. In: Pigeonpea Newslett, 12: 5-6.

\section{How to cite this article:}

Ashok Kumar Melkeri, S. K. Meti, D. M. Chandargi and Patil, S. S. 2020. Post-Harvest Activities and Marketing Behaviour Followed by the Farmers in Redgram Based Farming System. Int.J.Curr.Microbiol.App.Sci. 9(04): 1706-1711. doi: https://doi.org/10.20546/ijcmas.2020.904.200 